\title{
Upper Sun River Drainage Basin Origin Determined by Topographic Map Interpretation Techniques: Lewis and Clark and Teton Counties, Montana, USA
}

\author{
Eric Clausen \\ Independent Researcher, Jenkintown, PA \\ Email: eric2clausen@gmail.com
}

How to cite this paper: Clausen, E. (2019) Upper Sun River Drainage Basin Origin Determined by Topographic Map Interpretation Techniques: Lewis and Clark and Teton Counties, Montana, USA. Open Journal of Geology, 9, 257-277. https://doi.org/10.4236/ojg.2019.95018

Received: April 8, 2019

Accepted: May 11, 2019

Published: May 14, 2019

\section{Copyright $\odot 2019$ by author(s) and} Scientific Research Publishing Inc. This work is licensed under the Creative Commons Attribution International License (CC BY 4.0).

http://creativecommons.org/licenses/by/4.0/

(c) (i) Open Access

\begin{abstract}
A new and fundamentally different regional geomorphology paradigm in which massive south- and southeast-oriented meltwater floods flowed across the entire Missouri River drainage basin is tested by interpreting detailed topographic maps of the Montana upper Sun River drainage basin region by trying to explain origins of previously unexplained or poorly explained erosional landforms located upstream from Sun River Canyon (which cuts across Montana's north-to-south oriented Sawtooth Range). Mountain passes, through valleys, and other drainage divide low points along what are today high mountain ridges, including the North American east-west continental divide, are interpreted to be evidence of drainage routes that once crossed the region. These drainage divide crossings suggest that prior to erosion of present-day upper Sun River drainage basin valleys, massive floods moved in south directions across what are today the north-oriented Middle and South Fork Flathead River drainage basins into today's upper Sun River drainage basin area and carved a complex of diverging and converging channels into what was probably a low relief surface now represented by the crests of the region's highest mountain ridges. Further, the map evidence shows how a diverging complex of south- and southeast-oriented upstream Sun River drainage basin flood flow channels changed flow direction to cross the Sawtooth Range in a northeast direction before converging on the Montana plains at a location downstream from Sun River Canyon. The observed upper Sun River drainage basin area topographic map evidence is consistent with the new geomorphology paradigm predictions, in which massive south-oriented meltwater floods flowing across the rising rim of a continental ice sheet created deep "hole" (created by deep ice sheet erosion and ice sheet weight
\end{abstract}


caused crustal warping) are diverted to flow in northeast and north directions into and across deep "hole" space being opened up by ice sheet melting.

\section{Keywords}

Dearborn River, Flathead River, Missouri River, Montana Sawtooth Range, Mountain Pass Origin, New Geomorphology Paradigm, Transverse Drainage

\section{Introduction}

Typically published regional geologic histories do not address erosional landform histories such as how the regional drainage divides, valley orientations, and drainage divide crossings (e.g. mountain passes) originated. Drainage divides, valley orientations and drainage divide crossings are easily identified on detailed topographic maps and map interpretation techniques can be used to determine regional erosion histories, but geomorphologists rarely make such determinations. The scarcity of such determinations suggests the problem may be that from the perspective of their accepted paradigm geomorphologists are unable to satisfactorily explain the topographic map drainage divide, valley orientation, and drainage divide crossing evidence. In other words, these easy-to-observe erosional landforms are anomalous evidence the geomorphology research community's accepted paradigm cannot explain. According to Thomas Kuhn [1] scientists deal with anomalous evidence in one of three ways: first, an explanation is eventually found and the accepted paradigm continues without interruption; second, the anomalous evidence is identified and put on the back burner until an explanation can be found; and third, the anomalous evidence leads to a new paradigm and a battle over which paradigm should be used. A new geomorphology paradigm has emerged, at least for northern Missouri River drainage basin erosional landforms [2], and this paper's purpose is to demonstrate how that new paradigm explains upstream Sun River drainage basin drainage divides, valley orientations, and drainage divide crossings.

The Sun River originates in Montana's Lewis and Clark Range to the west of the Sawtooth Range and has a south-oriented North Fork and north-oriented South Fork, which drain approximately 100 kilometers of the North America east-west continental divide's eastern flank before joining to form the Sun River and to flow in an easterly direction across the Sawtooth Range (via Sun River Canyon) to reach the Montana plains and to join the northeast-oriented Missouri River (at Great Falls, Montana). The east-oriented Teton River drainage basin is to the north of the Sun River drainage basin and the southeast-oriented Dearborn River drainage basin is to the south with the Teton and Dearborn Rivers also flowing to the Missouri River, which after changing flow direction eventually joins the south-oriented Mississippi River with its water ultimately reaching the Gulf of Mexico. The northwest-oriented Middle Fork Flathead River drainage basin is to the north of the North Fork Sun River drainage basin and 
the north- and northwest-oriented South Fork Flathead River drainage basin is to the west. The Middle and South Forks of the Flathead River, after flowing in northwest directions, join the south-oriented North Fork Flathead River and form the south- and west-oriented Flathead River, which to the west of Figure 1 joins northwest-oriented Clark Fork with its water eventually reaching the Pacific Ocean. To the south of the north-oriented South Fork Sun River and western Dearborn River drainage basins is the west-oriented Blackfoot River drainage basin, which is also a Clark Fork tributary.

Sun River Canyon begins near where the south-oriented North Fork and north-oriented South Fork join to form the east-oriented Sun River, which then cuts across north-to-south trending ridges (some as much as 1000-meters higher than the river bed) of erosion resistant carbonate rock that makes up the Sawtooth Range. Narrow valleys underlain by less erosion resistant materials separate the high carbonate ridges resulting in a trellis drainage pattern with northand south-oriented streams flowing to the east-oriented Sun River. Today Gibson Reservoir (located behind 61-meter high Gibson Dam) floods the western canyon valley and when full the reservoir has a surface elevation of 1440 meters. Origins of most, if not all upstream Sun River drainage basin (upstream from Sun River Canyon) drainage divides (including North America's east-west continental divide), valley orientations, and drainage divide crossings (including numerous named mountain passes) are poorly understood. Further, while the

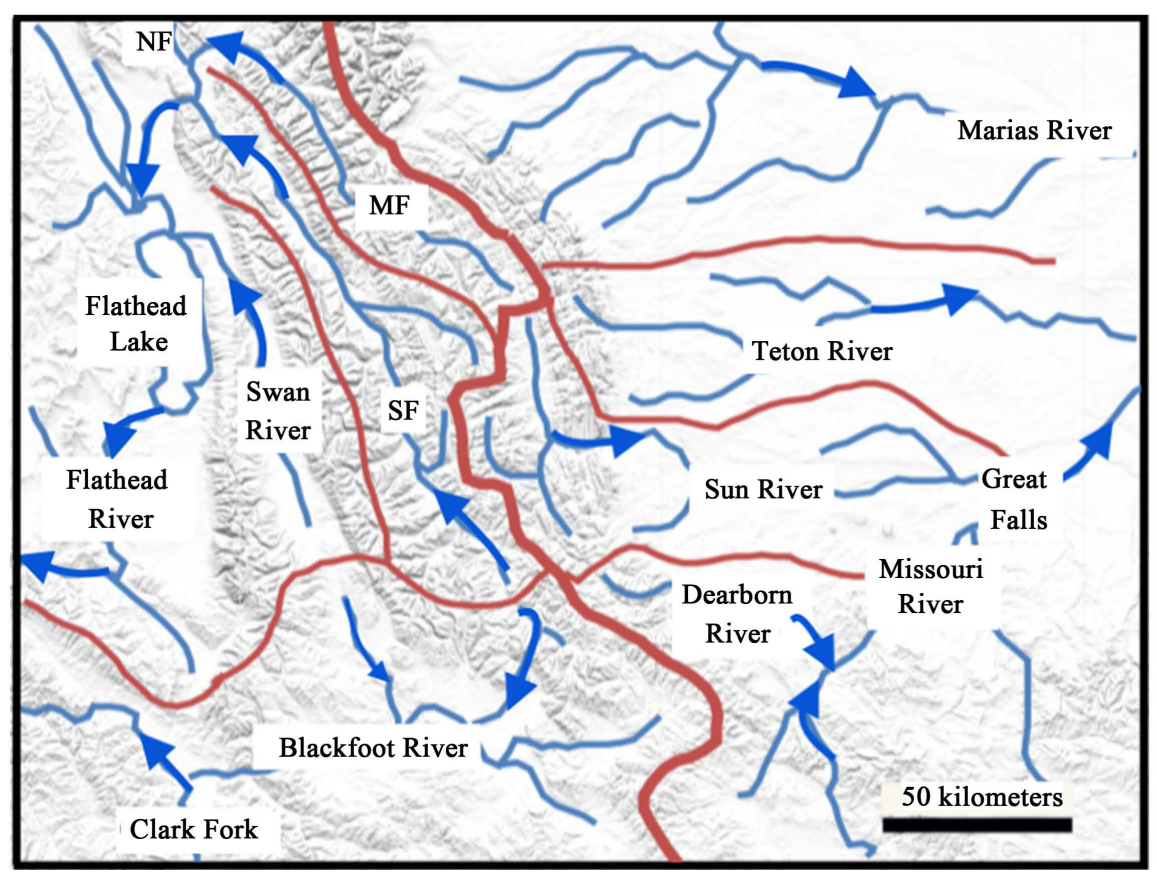

Figure 1. Modified map from United States Geological Survey (USGS) National Map website showing Sun River drainage basin relationship to adjacent rivers and drainage basins. The thick red line shows the North American east-west continental divide and thinner red lines show drainage divides between labeled river drainage basins. MF, NF, and SF identify the Middle, North, and South Forks of the Flathead River, which joins Clark Fork to the west of the figure. 
geology of the Sun River Canyon area is well-known, the origin of Sun River Canyon as an erosional landform is also poorly understood. The study reported here uses the upstream Sun River drainage basin drainage divides; valley orientations and depths, and the drainage divide crossings as observed on detailed topographic maps to determine how Sun River Canyon and those upstream Sun River drainage basin erosional landform features originated.

\section{Previous Work}

The most detailed geologic study of the upstream Sun River drainage basin area published to date was done by Mudge, who in two extensive United States Geological Survey (USGS) Professional Papers [3] [4], describes in detail Montana Sawtooth Range stratigraphy and structural geology. More recent publications on related regional topics include papers by Holl and Anastasio [5] and Fuentes et al. [6] [7] Geologic maps covering the entire Sun River Canyon area and upstream Sun River drainage basin are available at several different scales and the geologic maps include a 1:250,000 scale geologic map of the Choteau 1 degree by 2 degrees quadrangle [8] and 1:100,000 scale geologic maps of the $30^{\prime}$ by $60^{\prime}$ Choteau quadrangle [9] and of the $30^{\prime}$ by $60^{\prime}$ Dearborn River quadrangle [10]. The regional bedrock as mapped consists of many thrust fault slabs composed of various Precambrian, Paleozoic, and Mesozoic metamorphic and sedimentary rock units, with some localized Tertiary igneous intrusions also present. In terms of the regional geomorphology, most ideas about the regional drainage and glacial history can be traced back to work done by Calhoun [11] and Alden [12]. Included in those ideas and a fundamental component of the commonly accepted regional geomorphology paradigm is the north-oriented Montana Missouri River developed as a pre-glacial Bell River component [13]. The pre-glacial north-oriented Missouri River hypothesis led Sears [14] to propose that by Late Oligocene-Miocene time water from what is now much the Colorado River drainage basin flowed in a north direction through central Montana along the north-oriented Missouri River alignment.

Recent scientific literature discussing the Sun River Canyon and upstream Sun River drainage basin erosional landform origins is sparse. Many ideas expressed in the newer regional geomorphology literature can be traced back more than a century to Calhoun [11] who first described evidence for Sun River Glacier. He notes the large Sun River Glacier occupied the Sun River valley (upstream from Sun River Canyon) and his 1906 publication says, "The mouth of Sun River Canyon is narrow, but it was through this restricted opening that the ice pushed, tearing great blocks from the sides, cutting deep grooves in the valley walls, and smoothing and polishing the rock.... The sides of the canyon are glaciated to a height of over 1600 feet (488 meters)...." Maps included in Calhoun's publication and also in Alden's subsequent publication [12] show a large piedmont glacier extended out onto the high plains downstream from Sun River Canyon. Carra et al. [15] briefly discuss evidence obtained from the Sun River Canyon 
floor to conclude that "By 11,200 BP glacial ice had receded far up-valley and the Sun River Piedmont Glacier no longer existed". Calhoun and Alden show a much smaller piedmont glacier where the Dearborn River emerges from its canyon onto the plains and Foley [16] discusses how that "Pinedale age" piedmont glacier diverted the Dearborn River from its outwash valley. While not addressing the Sun River drainage basin Sears and Ryan [17] and Sears [14] in studies of nearby river valleys suggest the north-oriented Missouri River valley (into which the Sun River flows) existed prior to Late Oligocene time and may have once had a much more extensive drainage area.

Clausen [2] in several different publications has recently demonstrated how a new regional geomorphology paradigm (fundamentally different from the commonly accepted regional geomorphology paradigm) explains previously unexplained or poorly explained drainage divide, valley orientation, and drainage divide crossing evidence as observed on detailed topographic maps covering a number of different northern Missouri River drainage basin regions. Those papers demonstrate how the Bell River drainage system did not develop during pre-glacial time, but instead developed late during the melting of a large North American continental ice sheet. The new paradigm requires a large North American ice sheet created and occupied deep "hole" (formed by a combination of deep ice sheet erosion and of ice sheet caused crustal warping). Also defining the new paradigm is a requirement that the present-day Missouri River drainage system evolved while that large continental ice sheet existed and melted. The drainage system evolved as headward erosion of deep valleys captured immense south- and southeast-oriented glacial meltwater floods some of which flowed across rising mountain ranges which were probably being uplifted by ice sheet caused crustal warping. Some of these recent publications illustrate how topographic map evidence can be interpreted to show how headward erosion of the Missouri River valley explains Nebraska barbed tributaries [18] while other publications illustrate how topographic map evidence can be interpreted to demonstrate how north- and northeast-oriented Missouri River tributary valleys (that are usually considered to be pre-glacial Bell River drainage system components) eroded headward across massive southeast-oriented floods from a deep "hole" where a melting continental ice sheet was located. [2] [18] [19] [20] [21]. In still additional recent papers Clausen demonstrates how massive south- and southeast-oriented floods once flowed across high mountain ranges [22] [23].

\section{Research Method}

This paper focuses on one tributary drainage basin initially studied during the larger and still mostly unpublished Missouri River drainage basin landform origins project. Anomalous alluvium stimulated this author's interest and led to preliminary work that ultimately led to a decision to conduct a larger investigation [2]. After testing numerous unsuccessful hypotheses, thousands of detailed topographic maps were systematically studied with the goal of trying to deter- 
mine how the large Missouri River drainage system originated. That initial Missouri River drainage basin landforms origin research project used large mosaics of detailed hard copy topographic maps to investigate all Missouri River drainage basin drainage divides (all drainage divides between streams large enough to be shown on the detailed topographic maps) and took almost three years to complete (from 1999 to 2001). Each observed drainage divide was checked to identify divide crossings (through valleys, wind gaps, etc.) that provided evidence of previous drainage routes. Barbed tributaries, elbows of capture, asymmetric drainage divides, abandoned head cuts, and similar evidence were next used to determine how stream capture events had altered previous drainage routes to produce the drainage routes seen today. This evidence was used to try to reconstruct drainage systems and routes that existed prior to today's Missouri River drainage system.

Results of that initial research project suggested the southern Missouri River drainage system developed as valleys eroded headward from the Mississippi River valley across immense southeast-oriented floods, although much of what is today the northern Missouri River drainage system in Montana, northern Wyoming, western North Dakota, and northwestern South Dakota developed as north-oriented valleys eroded headward across the massive southeast-oriented floods. Further, some of the best evidence was located along what is now the North American east-west continental divide and large floods appeared to have flowed along alignments of what are today deep Canadian Rocky Mountain valleys including the modern-day Rocky Mountain Trench. The results were fundamentally different from anything in the published geology literature and challenged many commonly accepted ideas. The evidence was on large mosaics of detailed topographic maps and reviewers were unwilling to take the time to look so initial project results were never published. Technology changes enabled the Missouri River drainage basin landform origins research project to be repeated during the 2011-2013 time period using National Geographic TOPO software and topographic maps. More than 500 detailed research notes including digital copies the pertinent detailed topographic maps were posted in blog format at geomorphologyresearch.com and describe how more than 4000 different Missouri River drainage basin drainage divides originated. More recently much smaller segments of that second project, such as the segment this paper discusses, are being redone for publication purposes.

The study reported here used detailed topographic maps found at the USGS National Map website and was supplemented by the previously mentioned published literature and geologic maps. Map interpretation began by following drainage divides around the upstream Sun River drainage basin (upstream from Sun River Canyon) to identify mountain passes and other divide crossings including through valleys and saddles found on high mountain ridges. Each of these divide crossings was considered to be evidence that a drainage route had crossed the region prior to Sun River drainage system development. Next deeper mountain passes at the north and south ends of the north-to-south oriented up- 
stream Sun River drainage basin were studied to determine (as described below) whether those divide crossings had been eroded by water flowing in a north or south direction. After those determinations had been made similar determinations were made for other less deep divide crossings to check for consistency. Those map observations and determinations strongly suggested that immense south-oriented floods had been responsible for Sun River Canyon erosion and for development of the upstream Sun River drainage system.

\section{Results}

\subsection{North Fork Sun River and Sun River Pass}

Detailed topographic maps show the south-oriented North Fork Sun River flows in a broad mountain valley, located between high north-to-south oriented mountain ridge now forming North America's east-west continental divide to the west and high north-to-south oriented Sawtooth Range mountain ridges to the east. Several North Fork tributaries from the west flow in east or northeast directions although significant south- and southeast-oriented tributaries also exist. North Fork tributaries from the east usually flow in west or southwest directions. Except for Sun River Canyon and several mountain passes, high mountain ridges completely surround the North Fork Sun River drainage basin. The most intriguing deep mountain pass is Sun River Pass (1907 meters), which crosses an east-west oriented segment of North America's east-west continent divide and which links the north end of the south-oriented North Fork Sun River valley with the south end of a northwest-oriented tributary valley draining to the northwest-oriented Middle Fork Flathead River. On either side of Sun River Pass the continental divide elevation rises to between 2300 and 2500 meters (depending on how far one proceeds) meaning Sun River Pass is 400 - 600 meters deep. Sun River Pass is an erosional landform and is evidence that at one time a stream or river flowed across what is today the North American east-west continental divide.

There can be no question that water flowing in either a north or a south direction eroded Sun River Pass, but the direction of flow is not obvious unless the larger regional drainage pattern is considered. If north-oriented water flowing from the North Fork Sun River valley into the Middle Fork Flathead River valley eroded Sun River Pass, then flow in the North Fork Sun River valley has since been reversed. On the other hand, if south-oriented water from the Middle Fork Flathead River valley flowed into the North Fork Sun River valley, then flow in the Middle Fork Flathead River valley has since been reversed. Either alternative requires a major flow reversal to have taken place and the question can be asked, which of the two opposing flow directions across Sun River Pass leads to the simplest Sun River Canyon origin explanation? Water flowing in a north direction from Sun River Pass implies large volumes of west-oriented water probably moved from the Montana plains across the Sawtooth Range and was responsible for eroding the 1000-meter deep Sun River Canyon. Such an explanation is 
complicated at best and at worse defies common sense. Further, while the south-oriented North Fork Sun River does have some northeast-oriented (barbed) tributaries more of its tributaries are oriented in a south direction suggesting the North Fork Sun River drainage system developed with a south orientation. Without additional supporting evidence for north-oriented flow, the north-oriented hypothesis needs to be rejected.

To understand how water moving in a south direction could have eroded Sun River Pass the larger Flathead River drainage basin needs to be understood. Today the northwest-oriented Middle Fork, north-northwest oriented South Fork, and south-oriented North Fork join to form the south-oriented Flathead River, which after being joined by the north-oriented Swan River flows through Flathead Lake and eventually turns in a west direction to join northwest-oriented Clark Fork with water eventually reaching the Pacific Ocean. A through valley at the South Fork's southern end links north-northwest oriented Danaher Creek (which flows to the South Fork) with the southeast-oriented Dry Fork Blackfoot River. In fact, less than a kilometer of almost flat valley floor (elevation about 1635 meters) separates the two opposing drainage routes and there can be no question that water once flowed between the South Fork Flathead and Dry Fork Blackfoot valleys. Likewise, while the Swan River itself heads in the Mission Range a broad glacial moraine covered through valley (floor elevation at its deepest points is about 1268 meters) links its north-oriented valley with the south-oriented Clearwater River valley, which drains to the west-oriented Blackfoot River. Water flowing between the north-oriented Swan River valley and the south-oriented Clearwater River valley must have eroded that through valley prior to glacial moraine deposition, however channels cutting across the glacial moraines suggest some water flowed across the drainage divide after glacial moraine deposition.

The Flathead River is at the south end of the 1600-kilometer long Rocky Mountain Trench. While usually considered to be a structurally formed feature the Rocky Mountain Trench can also be viewed as the tectonically dismembered valley of what was once an immense south-oriented river. If so that large south-oriented river, which may have existed while regional uplift was taking place, may have split into multiple rivers where the Middle, North, and South Forks of the Flathead River now join to form diverging flow routes along what are today the northwest-oriented Middle Fork Flathead River, north-northwest South Fork Flathead River, and south-oriented Flathead River alignments. Further to the south the Flathead River route again split to flow around what may have been an actively rising north-to-south oriented Mission Range, with some water flowing along the modern-day Flathead River alignment and some water flowing in a south direction along the north-oriented Swan River and south-oriented Clearwater River alignment. If correctly interpreted south-oriented water flowing from the Rocky Trench initially eroded the northwest-oriented Middle Fork Flathead River Valley, Sun River Pass, and the North Fork Sun River valley. To do so the diverging south-oriented flow first moved along the 
Middle Fork Flathead River-Sun River Pass-North Fork Sun River alignment on a surface now represented by tops of the high ridges that Sun River Pass and Sun River Canyon now cut. Such a south-oriented river could have split near where the Sun River North and South Forks now join with some water continuing in a south direction and some of the water turning in an east direction to initiate Sun River Canyon as that water flowed onto the adjacent plains.

\subsection{South Fork Sun River and Straight Creek Pass}

The South Fork Sun River flows in a narrow north-oriented valley with several barbed tributaries from the west including the West Fork South Fork Sun River, which begins as a south-oriented stream (with north- and northeast-oriented barbed tributaries and also southwest-oriented tributaries) before turning in an easterly direction to join the South Fork Sun River. High mountain ridges making up the east-west continental divide surround the north-oriented South Fork Sun River headwaters valley and no deep mountain pass links that valley head with a south-oriented drainage route. However, two significant northwest oriented South Fork Sun River tributaries are located to the east of the north-oriented South Fork Sun River valley. The first is the northwest-oriented Straight Creek valley, which for much of its length is separated by a single high mountain ridge from the north-oriented South Fork Sun River valley. The second is the northwest-oriented Wood Creek valley, which is a Straight Creek tributary and which for much of its length is separated by a single high mountain ridge from the Straight Creek valley. What makes Straight Creek particularly interesting is 400-meter deep Straight Creek Pass (elevation 2055 meters), which links the northwest-oriented Straight Creek valley with the southeast-oriented Welcome Creek valley (which drains to the southeast-oriented Dearborn River). Further, a slightly lower elevation 400-meter deep pass links Halfmoon Creek (a north-northeast oriented Straight Creek tributary) to south-oriented Telegraph Creek which flows to the southeast- and northeast-oriented Dearborn River headwaters.

A diverging and converging river channel must have eroded these mountain passes as water flowed between the present-day Sun River and Dearborn River drainage basins and the question can be asked, in which direction did that water flow? If north-oriented water eroded the two passes then water in the southeast-oriented Dearborn River valley must have once flowed in a northwest direction. Such an interpretation requires water to have probably diverged from the north-oriented Missouri River. While Sears [14] suggested flow in a Late Oligocene-Early Miocene north-oriented Missouri River valley may have included drainage from much of the present-day Colorado River drainage basin there is no reason why in Montana such a river would have split with one diverging route flowing into and across what was probably an actively rising mountain range. Instead, the southeast-oriented Dearborn River joins the north-oriented Missouri River as a barbed tributary and can alternatively be interpreted to be evidence that flow in the Missouri River valley was once in a south direction 
with the water possibly continuing in a south direction to join the Colorado River. The presence of south-oriented barbed tributaries to the north-oriented South Fork Sun River suggests a reversal of flow in the South Fork valley is much more likely than a flow reversal in the Dearborn River valley. In addition, two recent papers [22] [23] analyzing mountain passes crossing mountain ranges surrounding the southwest Montana Big Hole, Beaverhead, and Boulder River drainage basins describe considerable geomorphic evidence that suggests immense south-oriented floods once crossed the entire region.

\subsection{South Fork Sun River and Wood-Ford Creek Through Valley and Other Through Valleys}

Just as intriguing as the Straight Creek Pass area is the 600-meter deep through valley (elevation 1770 - 1780 meters) linking northwest-oriented Wood Creek (flowing to northwest-oriented Straight Creek) with southeast- and northeast-oriented Ford Creek, which flows across the Sawtooth Range southern end before its water eventually reaches the plains and the Sun River (downstream from Sun River Canyon). Without question water eroded this deep through valley (see Figure 2) and the question can again be asked, was the water flowing from the Sun River drainage basin upstream from Sun River Canyon to the Sun River drainage basin downstream from Sun River Canyon, or did the water flow in the other direction? In either case, there was enough water flowing across the Sawtooth Range to erode not just Sun River Canyon, but also the Wood Creek-Ford Creek through valley. Logically a south-oriented stream of water flowing from upstream of Sun River Canyon to the Sun River downstream from Sun River Canyon is much more likely to have eroded the Wood Creek-Ford Creek

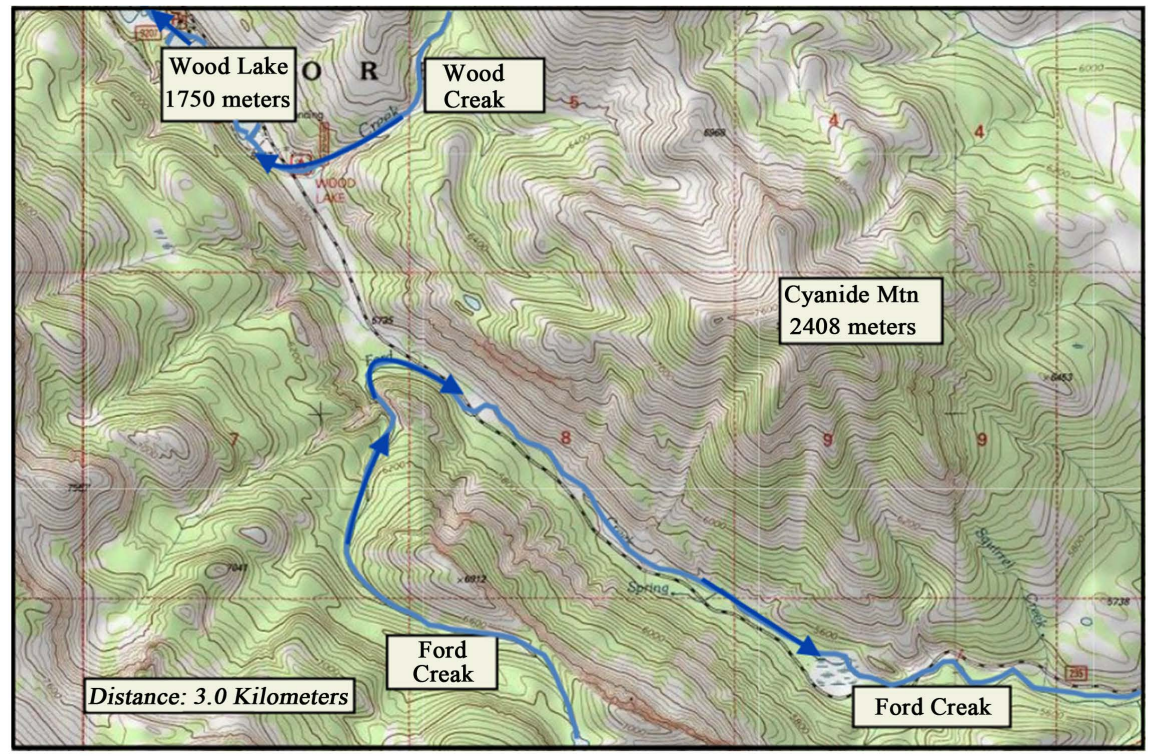

Figure 2. Modified topographic map from USGS National Map website showing the Wood Creek-Ford Creek through valley. Wood Creek water flows to the Sun River upstream from Sun River Canyon while Ford Creek water flows to the Sun River downstream from Sun River Canyon. The contour interval is 40 feet (12 meters). 
through valley than water flowing in the opposite direction and such a direction is consistent with the determination that water in the present-day northwest-oriented Straight Creek valley once flowed in a southeast direction to the Dearborn River and is also consistent with the determination that large volumes of water once flowed in a south direction across Sun River Pass, initially on a surface now represented by today's highest regional ridge crests.

Surprisingly the Wood Creek-Ford Creek through valley is not alone. To the south of the Wood Creek-Ford Creek through valley a 250-meter deep mountain pass (floor elevation about 2225 meters) links a northwest- and southwest-oriented Straight Creek tributary valley (Crown Creek) with the northeastand southeast-oriented Petty Creek valley, which drains to northeast-oriented Smith Creek and the Sun River (downstream from Sun River Canyon). A short distance to the southeast of Straight Creek Pass is Welcome Pass (floor elevation 1871 meters), which links southeast-oriented Welcome Creek (draining to the Dearborn River) with northeast-oriented Moudess Creek-Smith Creek, which also flows across the Sawtooth Mountains with its water eventually flowing to the Sun River (downstream from Sun River Canyon). Welcome Pass is the lowest point on a 6- to 7-kilometer long lower-elevation section of what elsewhere is a 2500-meter high ridge, which for much of its length forms the drainage divide between the 400-meter deep Straight Creek-Dearborn River through valley and headwaters of streams that ultimately flow in northeast directions to the Sun River (downstream from Sun River Canyon). A large river or flood flowing on the present-day Welcome Creek alignment must have diverged in the Welcome Pass area with one branch flowing in a southeast direction (to join the Dearborn River) and the other branch flowing in a northeast direction (to reach the Sun River downstream from Sun River Canyon). Further, the Dearborn River after flowing between mountain ridges in a southeast direction turns in an east and then northeast direction to cross the Sawtooth Range southern end and to flow out onto the plains before turning to flow in a southeast direction again.

The Straight Creek-Wood Creek-Ford Creek, Straight Creek-Crown Creek-Petty Creek-Smith Creek, Straight Creek-Welcome Creek-Moudess Creek-Smith Creek, and Straight Creek-Dearborn River valley routes illustrate how large volumes of south-oriented water did not flow through Sun River Canyon, but instead flowed in a southeast direction along what is now the northwest-oriented Straight Creek alignment, with the water diverging into multiple northeast-oriented flow routes to cross the Sawtooth Range before most of those diverging routes appear to have converged again. In other words, valleys, as seen on topographic maps show that at one-time water moved on multiple diverging and converging channels to cross what are today high Sawtooth Range ridges. As the diverging (and converging) flow routes eroded deeper valleys into the Sawtooth Range the water became concentrated in the deepest channels and one by one shallower valleys were abandoned. First to be abandoned was the Straight Creek-Crown Creek-Petty Creek-Smith Creek route with routes across Straight Creek Pass abandoned next. The Wood Creek-Ford Creek through valley route was finally 
abandoned when Sun River Canyon captured all of what must have been massive south-oriented flood flow entering what is today the upstream Sun River drainage basin.

Today the Dearborn River after flowing in a northeast direction across the Sawtooth Range turns to flow in more of a southeast direction, however, an abandoned valley where the Dearborn River first flows out onto the plains continues further in a northeast direction. Foley [16] interprets the abandoned valley to have been used when a piedmont glacier diverted the Dearborn River. An alternate interpretation of the abandoned valley could be that floodwaters emerging from the Dearborn River canyon diverged with some water moving in a northeast direction toward the Sun River (downstream from Sun River Canyon) and other water flowing in a southeast direction as the Dearborn River now does. The alternate interpretation implies the northeast-oriented water was moving toward northeast-oriented flow moving along the present-day Missouri River alignment while the southeast-oriented flow was moving towards south-oriented flow on what is today the north-oriented Missouri River alignment. If correct this interpretation strongly supports the interpretation that the large volumes of south-oriented water had originated as immense ice-marginal meltwater floods from a large continental ice sheet that had created and occupied a deep "hole" and that ice sheet melting was opening up deep "hole" space so as to capture and divert the south-oriented ice-marginal meltwater floods in north and northeast directions onto and across the melting ice sheet's floor.

\subsection{Spotted Bear Pass, the Chinese Wall, Unnamed Passes, and Camp Creek Pass}

The detailed topographic maps show hundreds of additional mountain passes crossing drainage divides both within and surrounding the upstream Sun River drainage basin, although most of the passes are not as deep as the above described divide crossings. One interesting area to observe these additional divide crossings is in a Sun River drainage basin western extension (Figure 3) where today the north-to-south oriented east-west continental divide jogs in west direction for approximately 8 kilometers, resumes its south direction for approximately 50 kilometers, jogs back in an east direction for approximately 8 kilometers, and then continues in a southeast direction. Rock Creek and Moose Creek, which are northeast-oriented and barbed North Fork Sun River tributaries, drain this western extension's northern half while the south- and east-oriented West Fork South Fork Sun River drains the southern half and is joined by short northeast- and southwest-oriented tributaries. The maps show the two northeast-oriented North Fork Sun River tributaries and the northeast-oriented West Fork South Fork Sun River tributaries head along the north-to-south oriented and east-facing Chinese Wall, which is a steep cliff that stands several hundred meters high. Spotted Bear Pass (SBP) crosses the northern continental divide east-to-west jog. Camp Creek Pass (CCP) crosses the southern continental divide west-to-east jog, and unnamed passes cross high drainage divides 


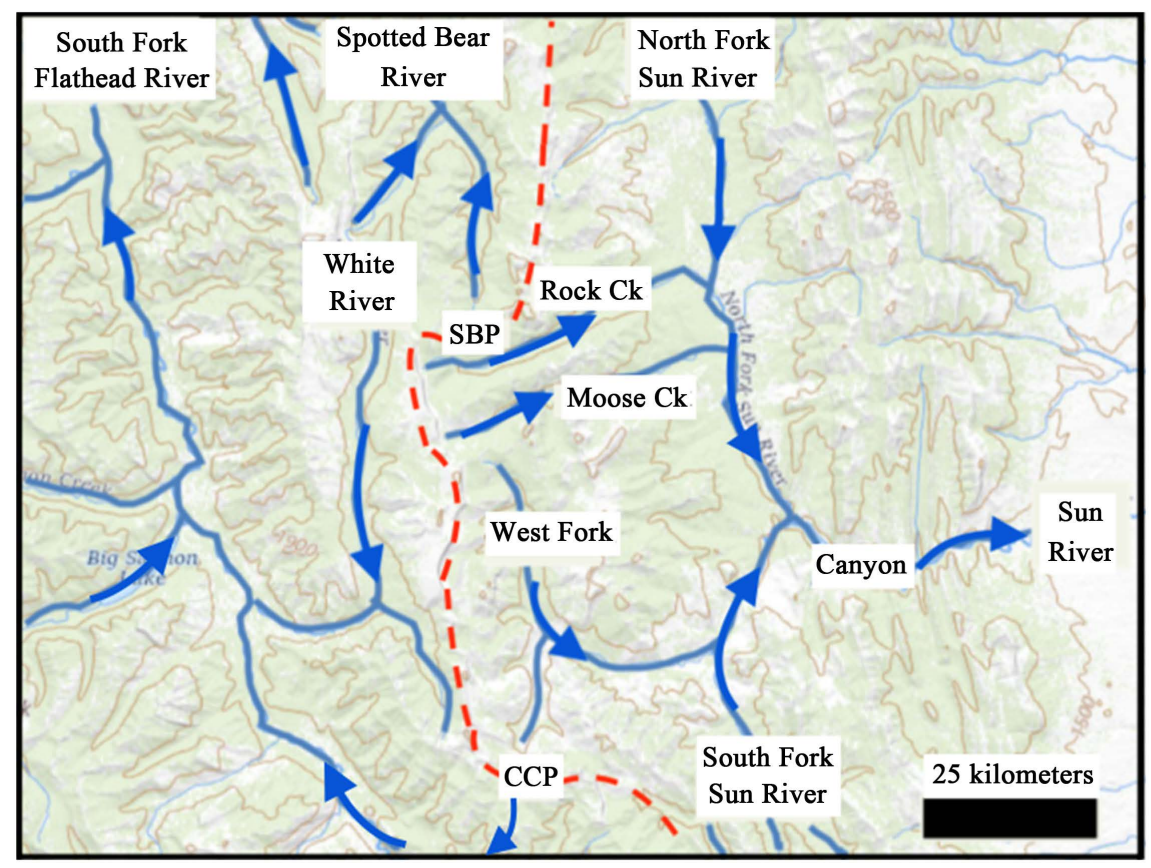

Figure 3. Modified map from USGS National Map website showing the Sun River drainage basin western extension. Red dashed line shows east-west continental divide, SBP shows Spotted Bear Pass location, CCP shows Camp Creek Pass location. Contour interval is 500 meters.

between Rock and Moose Creek and between Moose Creek and the West Fork South Fork Sun River.

Spotted Bear Pass (2060 meters) is more than 400 meters deep and crosses the east-to-west continental divide segment at the Sun River drainage basin's western extension north end. To the north of Spotted Bear Pass is the north-oriented Spotted Bear River valley draining to the north-oriented South Fork Flathead River. To the south is a southeast-oriented tributary to northeast-oriented Rock Creek, which flows to the south-oriented North Fork Sun River. Camp Creek Pass (2177 meters) is more than 500 meters deep and crosses the west-to-east continental divide segment at the Sun River drainage basin's western extension's southern end. Between these two passes, ridges with high points exceeding 2600 meters separate the northeast-oriented Rock and Moose Creek valleys and the Moose Creek valley from the south-oriented West Fork South Fork Sun River. Moose Ridge (to the south of Spotted Bear Pass and between Rock and Moose Creeks) is crossed by 300-meter deep notches. Low points on these Moose Creek Ridge divide crossings are slightly higher than 2250 meters. To the south of the Moose Creek valley even deeper notches (although with similar floor elevations) lead to south-oriented valleys draining to the south- and east-oriented West Fork South Fork Sun River. The West Fork South Fork Sun River turns to flow an east direction at the point where it is joined by north-oriented Ahorn Creek, which has a north-oriented tributary (Lost Fork) that originates at Camp Creek Pass. South-oriented Camp Creek originates at Camp Creek Pass and flows to north-oriented Danaher Creek, which flows to the north-oriented South Fork 
Flathead River. North-oriented Danaher Creek originates approximately $20 \mathrm{ki}$ lometers to the southeast of where south-oriented Camp Creek joins it (as a barbed tributary) and as previously described a short through valley (elevation approximately 1635 meters) links the north-oriented Danaher Creek valley with the southeast-oriented Dry Fork Blackfoot River valley.

High elevation mountain passes in the Sun River drainage basin western extension area illustrate how massive south-oriented floods moved across the larger upstream Sun River drainage basin on a surface now represented by 2600 -meter high ridge tops before eroding the present-day deep valley system. To the west of the western extension is the north-oriented South Fork Flathead River valley. Between that north-oriented South Fork Flathead River valley and the western extension's 50-kilometer long north-to-south oriented west boundary (i.e. the east-west continental divide) is the south-oriented White River valley, which originates to the west of Spotted Bear Pass and which after approximately 40 kilometers makes a U-turn to join the north-oriented South Fork Flathead River as a barbed tributary. To the east of the White River U-turn and of the continental divide the south-oriented West Fork South Fork Sun River also makes a U-turn so as to flow in an east direction and to join the north-northeast oriented South Fork Sun River. Two mountain passes (floor elevations of about 2085 and 2190 meters) link the south-oriented White River valley with two north-oriented valleys draining to the north-oriented Spotted Bear River (flowing to the South Fork Flathead River). These two mountain passes are where south-oriented floodwaters flowing on what is today the north-oriented Spotted Bear River alignment diverged from south-oriented floodwaters flowing across what is today Spotted Bear Pass so as to flow in a south direction along the south-oriented White River alignment.

What happened to create drainage routes seen today was south-oriented floodwaters flowing on a surface now represented by 2500 meter high or higher ridge tops diverged to flow on opposite sides of today's east-west continental divide (where some elevations now exceed 2600 meters) and then converged to flow into (and probably across) what is now the Blackfoot River drainage basin. Floodwaters moving along the eastern route at first flowed across the present-day Sun River drainage basin western extension and were joined by southwest-oriented floodwaters diverging from south-oriented floodwaters on what is today the Middle Fork Flathead River-Sun River Pass-North Fork Sun River alignment to flow in southwest directions along what are today the northeast-oriented Rock and Moose Creek alignments. What at that time was a deep south-oriented valley (with a floor elevation of 2177 meters) eroded headward across what is now Camp Creek Pass before an even deeper east-oriented valley eroded headward along one of the many diverging flood flow routes and diverted the south-oriented flow to move along what is today the east-oriented West Fork South Fork Sun River segment and then probably along the Wood Creek-Ford Creek through valley and Straight Creek-Welcome Creek-Dearborn River valley alignments. Headward erosion of the deep south-oriented North 
Fork Sun River valley (probably from what was then an actively eroding Sun River Canyon and also probably from the Straight Creek Pass and Wood Creek-Ford Creek through valley routes next ended south-oriented flood flow to the West Fork South Fork Sun River drainage basin by beheading and reversing the diverging (southwest-oriented) flood flow routes along the Moose Creek and the Rock Creek alignments so as to capture south-oriented floodwater moving across Spotted Bear Pass and to divert that water in a northeast direction to the deeper, but south-oriented North Fork Sun River valley.

South-oriented flood flow to the Sun River drainage basin western extension by that time had been concentrated on the Spotted Bear Pass route and ended when flood flow moving on the south-oriented White River alignment captured all of the flood flow that had been moving across Spotted Bear Pass. That capture caused a flow reversal on the Spotted Bear River southern end, although water on the Spotted Bear River northern end was still moving in a south direction to reach the south-oriented White River valley. At the same time, south-oriented water continued to flow along the Middle Fork Flathead River-Sun River Pass-North Fork Sun River alignment and also on the South Fork Flathead River alignment. In time deepening of the South Fork Flathead River valley caused a flow reversal along the Spotted Bear River north end and ended south-oriented flood flow into the White River valley. South-oriented flood flow into the upstream Sun River drainage basin next ended when deeper south-oriented valleys on the South Fork Flathead River and Flathead River alignments beheaded and reversed south-oriented flood flow on the Middle Fork Flathead River alignment to create Sun River Pass and the northwest-oriented Middle Fork Flathead River. Finally deepening of the south-oriented Flathead River valley beheaded and reversed south-oriented flood flow moving on the South Fork Flathead River alignment to create the previously described Danaher Creek-Dry Fork Blackfoot River through valley and the north-oriented South Fork Flathead River.

\subsection{Glacial Erosion Evidence in Sun River Canyon and in the Upstream Sun River Drainage Basin}

Calhoun [11] suggested glacial ice filled the upstream Sun River drainage basin and flowed through Sun River Canyon onto the plains where a piedmont glacier formed. While subsequent investigators frequently cite Calhoun's work a search for references describing more recent detailed investigations of upstream Sun River drainage basin glaciation was unsuccessful. Assuming Calhoun's descriptions are correct glacial ice and meltwater probably played a role in eroding the upstream Sun River drainage basin. The USGS National Map website was used to test such a possibility by using detailed topographic maps to look for glacial landforms in the upstream Sun River drainage basin and also in Calhoun's described Sun River Canyon (Figure 4) and downstream piedmont glacier areas. Map evidence shows many upstream Sun River drainage basin alpine glacial features, especially in the Sun River drainage basin western extension area, including cirques, aretes, horns, oversteepened cliffs (e.g. the Chinese Wall), 


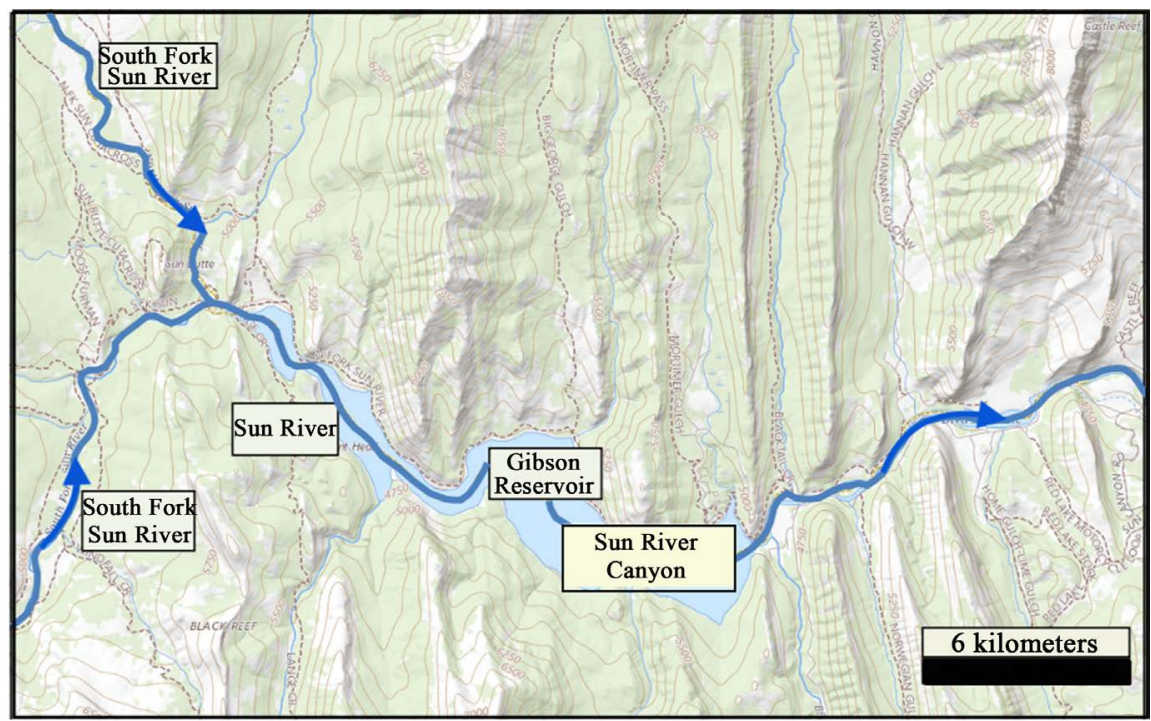

Figure 4. Modified map from the USGS National Map website showing the Sun River Canyon area. The contour interval is 250 meters. Note how the canyon twists and turns and is not streamlined like in a glaciated valley.

tarns, streamlined and U-shaped valleys, and even a few small permanent snow or ice fields. However, the glacial landforms are much less obvious in the upstream Sun River drainage basin area than in Glacier National Park (about 90 kilometers to the north) or in the Mission Range area (about 80 kilometers to the southwest).

While valley glaciers appear to have streamlined, deepened, and maybe even widened some upstream Sun River drainage basin valleys, especially in the drainage basin's western extension area, large volumes of glacial ice probably did not move across most high ridges now separating those valleys. Further glaciation does not appear to have significantly altered the above described mountain passes or through valleys. If correctly interpreted floodwaters initially eroded all the upstream Sun River drainage basin valleys and glaciers formed in the flood carved valleys after the immense south-oriented floods had ended. Interestingly, topographic map study did not find convincing evidence to support Calhoun's interpretation that glacial ice forced its way through Sun River Canyon. The canyon walls are not streamlined in a manner typical of glaciated valleys (Figure 4). Calhoun's interpretation also implies lateral moraines should be present in low areas between the canyon's erosion resistant ridges, but convincing map evidence for such lateral moraines was not found. Further, while the detailed topographic maps suggest something very unusual produced the landscape where Calhoun's Sun River piedmont glacier was proposed to exist; powerful catastrophic floods emerging from Sun River Canyon may have produced such landform features. Calhoun's photos do show large boulders in the piedmont glacier region and whether large floods could have moved those boulders can probably be debated. There is no doubt, however, that a powerful erosive force tore through Sun River Canyon, but the canyon shape and the lack of convincing 
map evidence for lateral moraines suggest the powerful force may not have been a glacier as Calhoun suggested.

Calhoun also describes glacial evidence in Sun River Canyon extending 1600 feet (488 meters) upwards from the canyon floor. His description does not say where in Sun River Canyon that measurement was made nor does he give any information as to how the measurement was made, and study of detailed topographic maps did not find convincing map evidence to indicate where that boundary between glaciated and unglaciated canyon walls might exist. However, based on Calhoun's description the elevation of the boundary between the glaciated canyon slopes and the unglaciated canyon slopes should be somewhere between 1800 and 1900 meters. If so, Calhoun's boundary elevation is only slightly higher than the Wood Creek-Ford Creek through valley floor elevation. It is possible the boundary Calhoun's description describes is not the boundary between glaciated lower canyon slopes and non-glaciated upper canyon slopes, but instead the boundary between where south-oriented floodwaters flowing into and through the upstream Sun River drainage basin moved along two or more different routes to reach the Montana plains and where those floodwaters became concentrated so as to only flow through Sun River Canyon. If so the volumes of flood water moving through Sun River Canyon may have been significantly greater as the canyon eroded below that boundary and the increased flood flow may account for the differences Calhoun observed.

\section{Discussion}

Detailed topographic maps permit mountain passes and less obvious low points notched into high mountain ridges to be used to reconstruct how immense south-oriented floods flowed across the present-day upstream Sun River drainage basin and carved a large diverging and converging channel complex into a surface now preserved along the region's highest ridge crests. Atwood [24] discusses the concept of a Rocky Mountain peneplain and how "at the close of the mid-Tertiary period of erosion and alluviation, virtually all the main streams of the Rocky Mountain region were flowing in places over buried mountain ranges." No convincing topographic or geologic map evidence was found to suggest the upstream Sun River drainage basin thrust fault slabs had been buried, instead, the underlying geologic structures appear to have been beveled off perhaps even during earlier stages of the massive south-oriented flood flow. In any case, the massive south-oriented floods at one time flowed across a low relief surface that no longer exists. For deep valley erosion to occur that low relief surface had to be at a higher elevation than the adjacent Montana plains, although Rocky Mountain uplift may have been occurring as the floodwaters flowed across the region and floodwater erosion may also have been lowering the Montana plains.

The question can validly be asked, where did these immense south-oriented floods originate? Montana geology literature, including books for the general 
public (e.g. [25]), rarely address major mountain passes and other less well-known low points now notched into high mountain ridges and does not address where water that eroded those landform features came from. However, as shown here the detailed topographic map evidence for massive south-oriented flood flow is excellent and can be traced headward on the topographic maps to a Rocky Mountain Trench source. Map study suggests the Rocky Mountain Trench is the (tectonically) dismembered valley of an immense southeast-oriented river, although few if any, published Rocky Mountain Trench descriptions consider the Trench as such. Instead, Clague [26] provides a typical description when he says the southern Rocky Mountain Trench "consists of tectonic depressions formed by Cenozoic block faulting superposed on late Cretaceous allochthonous fold and thrust features" and which served as "a major outlet valley of the Cordilleran Ice Sheet" The Cordilleran Ice Sheet, as usually recognized and described, almost certainly postdates the floods described here and probably existed when glaciers filled upper Sun River drainage basin valleys meaning the massive south-oriented floodwaters described here came from a source that preceded the Cordilleran Ice Sheet (at least as usually described) and from what must have been a much a larger water source that coexisted with Rocky Mountain regional uplift. The commonly accepted regional geomorphology paradigm does not recognize such a flood source, which is probably why the Montana geology literature rarely attempts to explain mountain pass origins, the many Montana rivers that make U-turns and/or with barbed tributaries, the east-west continental divide origin, or other interesting landform features such as the southeast-northeast oriented Wood Creek-Ford Creek through valley.

In the Missouri River drainage basin (of which the Sun River drainage basin is a component) the pre-glacial north-oriented Bell River drainage system defines the commonly accepted geomorphology paradigm while immense south- and southeast-oriented meltwater floods from a large continental ice sheet located in an ice sheet created deep "hole" (created by deep ice sheet erosion and by ice sheet caused crustal warping) define the recently proposed geomorphology paradigm. Paradigms according to Kuhn [1] are frameworks of rules governing how a scientific discipline conducts its research and by themselves are neither correct nor incorrect, but should be judged by their ability to explain evidence and to open up research opportunities. The new geomorphology paradigm as this paper demonstrates explains upper Sun River drainage basin area detailed topographic map evidence that to date the commonly accepted regional geomorphology paradigm has not enabled investigators to explain. While fleshing out all of the new geomorphology paradigm details will be a long-term process this paper and this author's other recent papers (cited and not cited in this paper) demonstrate for a diverse set of northern Missouri River drainage basin regions how the new regional geomorphology paradigm framework of rules permits investigators to explain previously unexplained detailed topographic map landform evidence. 


\section{Conclusion}

A new geomorphology paradigm permits mountain passes, through valleys, and other low points notched into what are today high mountain ridges (when observed on detailed topographic maps) to be used to reconstruct how massive south-oriented floods once flowed on a low relief surface (now represented by the tops of high mountain ridges) and systematically carved deep valleys to create what is today the upstream Sun River drainage basin. The south-oriented floods can be traced headward to the Rocky Mountain Trench and were most likely from a large continental ice sheet. The continental ice sheet as the new paradigm requires was located in a deep "hole" that had been created by a combination of deep ice sheet erosion and by ice sheet caused crustal warping. Canadian and Montana Rocky Mountains are located along that deep "hole's" southwest rim which was probably rising while the massive south-oriented meltwater floods flowed across it. Ice sheet melting eventually opened up lower elevation routes on the ice sheet's deep "hole" floor that captured south- and southeast-oriented ice-marginal floods and diverted those floodwaters in northeast directions. Sun River Canyon and abandoned valleys crossing the Sawtooth Range (e.g. Wood Creek-Ford Creek through valley) document where immense floods that had been flowing across the upstream Sun River drainage basin area in a large south-oriented diverging and converging channel complex were diverted to flow in east and northeast directions across the Sawtooth Range with the Sun River Canyon route ultimately capturing all of the flood flow moving out of the present-day upstream Sun River drainage basin.

\section{Acknowledgements}

Preliminary work leading to the larger Missouri River drainage basin landform origins research project of which this paper describes one component was begun while employed as a faculty member at Minot State University in North Dakota where library staff, other faculty members, and several students helped to develop the needed detailed topographic map collections.

\section{Conflicts of Interest}

The authors declare no conflicts of interest regarding the publication of this paper.

\section{References}

[1] Kuhn, T.S. (1970) The Structure of Scientific Revolutions. Second Edition, University of Chicago Press, Chicago, 210 p.

[2] Clausen, E. (2018) Deep Erosion by Continental Ice Sheets: A Northern Missouri River Drainage Basin Perspective: North America. Current Research in Geoscience, 8, 27-38.

[3] Mudge, M.R. (1972) Pre-Quaternary Rocks in the Sun River Canyon Area, Northwestern Montana. United States Geological Survey Professional Paper 663-A, 142 p. https://doi.org/10.3133/pp663A 
[4] Mudge, M.R. (1972) Structural Geology of the Sun River Canyon and Adjacent Areas, Northwestern Montana. United States Geological Survey Professional Paper 663-B, 52 p. https://doi.org/10.3133/pp663B

[5] Holl, J.E. and Anastasio (1992) Deformation of a Foreland Carbonate Thrust System, Sawtooth Range. Montana: Geological Society of America, 104, 944-953. https://doi.org/10.1130/0016-7606(1992)104<0944:DOAFCT >2.3.CO;2

[6] Fuentes, F., DeCelles, P.G., Constenius, K.N. and Gehreds, G.E. (2011) Evolution of the Cordilleran Foreland Basin System in Northwestern Montana, USA. Geological Society of America Bulletin, 123, 507-533. https://doi.org/10.1130/B30204.1

[7] Fuentes, F., DeCelles, P.G. and Constenius, K.N. (2012) Regional Structure and Kinematic History of the Cordilleran Fold-Thrust Belt in Northwestern Montana, USA. Geosphere, 8, 1104-1128. https://doi.org/10.1130/GES00773.1

[8] Mudge, M.R., Earnhart, R.L., Whipple, J.W. and Harrison, J.E. (1982) Geologic and Structure Map of the Choteau 1 Degree x 2 Degree Quadrangle, Western Montana. United States Geological Survey, Miscellaneous Investigations Series Map I-13000, Scale 1:250,000. https://doi.org/10.3133/i1300

[9] Berg, R.B. (2008) Geologic Map of the Choteau 30’ x 60' Quadrangle, North Central Montana. Montana Bureau of Mines and Geology, Open-File Report 571. https://doi.org/10.3133/ofr20061329

[10] Vuke, S.M. (2014) Preliminary Geologic Map of the Dearborn River 30’ x 60' Quadrangle, West-Central Montana. Montana Bureau of Mines and Geology Open-File Report 649. https://doi.org/10.3133/ofr20061329

[11] Calhoun, F.H.H. (1906) The Montana Lobe of the Keewatin Ice Sheet. United States Geological Survey Professional Paper 50, 62 p. https://doi.org/10.3133/pp50

[12] Alden, W.C. (1932) Physiography and Glacial Geology of Eastern Montana and Adjacent Areas. United States Geological Survey Professional Paper 174, 133 p. https://doi.org/10.3133/pp174

[13] Jackson, L. (2018) The Paleo-Bell River: North America's Vanished Amazon. Earth, 63, 74-81.

[14] Sears, J.W. (2013) Late Oligocene-Early Miocene Grand Canyon: A Canadian Connection? GSA Today, 23, 4-10. https://doi.org/10.1130/GSATG178A.1

[15] Carra, P.E., Short, S.K. and Wilcox, R.E. (1986) Deglaciation of the Mountainous Region of Northwestern Montana, U.S.A., as Indicated by Late Pleistocene Ashes. Arctic and Alpine Research, 18, 317-325. https://doi.org/10.2307/1550889

[16] Foley, M.G. (1980) Quaternary Diversion and Incision, Dearborn River, Montana. Geological Society of America Bulletin, 91, 2152-2188. https://doi.org/10.1130/GSAB-P2-91-2152

[17] Sears, J.W. and Ryan, P. (2003) Cenozoic Evolution of the Montana Cordillera: Evidence from Paleovalleys. In: Raynolds, R. and Flores, J., Eds., Cenozoic Paleo-Geography of Western US: Rocky Mountain Section, Society of Exploration Paleontologists and Mineralogists, Denver, 289-301.

[18] Clausen, E. (2018) Interpreting Topographic Map Evidence Related to Northeast Nebraska Barbed Tributaries and Drainage Routes, USA. Journal of Geography and Geology, 10, 66-79. https://doi.org/10.5539/igg.v10n2p66

[19] Clausen, E. (2017) Using Map Interpretation Techniques for Relative Dating to Determine a Western North Dakota and South Dakota Drainage Basin Formation Sequence, Missouri River Drainage Basin, USA. Journal of Geography and Geology, 9 , 1-18. https://doi.org/10.5539/jgg.v9n4p1 
[20] Clausen, E. (2018) Geomorphic History of the Beaver Creek Drainage Basin as Determined from Topographic Map Evidence: Eastern Montana and Western North Dakota, USA. Journal of Geography and Geology, 10, 79-91. https://doi.org/10.5539/jgg.v10n3p79

[21] Clausen, E. (2019) Origin of the Redwater River Drainage Basin Determined by Topographic Map Interpretation: Eastern Montana. Journal of Geography and Geology, 11, 42-54. https://doi.org/10.5539/jgg.v11n1p42

[22] Clausen, E. (2017) Origin of Mountain Passes across Continental Divide Segments Surrounding the Southwest Montana Big Hole and Beaverhead River Drainage Basins, USA. Open Journal of Geology, 7, 1362-1385.

https://doi.org/10.4236/ojg.2017.79091

[23] Clausen, E. (2017) Analysis of Mountain Passes along the East-West Continental Divide and Other Drainage Divides Surrounding the Boulder River Drainage Basin, Jefferson County, Montana, USA. Open Journal of Geology, 7, 1603-1624. https://doi.org/10.4236/ojg.2017.711108

[24] Atwood, W.W. (1940) The Physiographic Provinces of North America. Ginn and Company, New York, $536 \mathrm{p}$.

[25] Alt, D. and Hyndman, D.W. (1986) Roadside Geology of Montana. Mountain Press Publishing Company, Missouls, 427 p.

[26] Clague, J.J. (1975) Late Quaternary Sediments and Geomorphic History of the Southern Rocky Mountain Trench. Canadian Journal of Earth Science, 12, 595-605. https://doi.org/10.1139/e75-054 